\title{
CARCASS QUALITY, MARBLING AND CHOLESTEROL CONTENT OF MALE BALI CATTLE FED FERMENTED COCOA SHELL
}

\author{
E. Suryanto ${ }^{1}$, Bulkaini ${ }^{2}$, Ashari ${ }^{2}$ and I . W. Karda ${ }^{2}$ \\ ${ }^{1}$ Faculty of Animal Science, Gadjah Mada University, \\ Jl Fauna 3 Kampus UGM, Bulaksumur, Yogyakarta 55281 - Indonesia \\ ${ }^{2}$ Faculty of Animal Science, Mataram University, \\ Gamong Campus, Jl Majapahit, Mataram - Indonesia \\ Corresponding E-mail: edi_ugm@ugm.ac.id
}

Received October 02, 2014; Accepted November 22, 2014

\begin{abstract}
ABSTRAK
Penelitian ini bertujuan untuk mengetahui kualitas karkas, persentase komponen non karkas, marbling dan kandungan kolesterol daging sapi Bali jantan yang diberi pakan berbasis kulit buah kakao (KBK) fermentasi. Materi yang digunakan dalam penelitian ini adalah 9 ekor sapi Bali jantan berumur 1,5-2 tahun dan berat 165-175 kg. Sapi Bali dibagi secara acak ke dalam 3 kelompok perlakuan pakan. Kelompok P0 diberi pakan mengandung 30\% KBK yang difermentasi tanpa tambahan inokulum dan $70 \%$ jerami jagung, kelompok P1 diberi pakan mengandung 30\% KBK yang difermentasi dengan cairan rumen dan $70 \%$ jerami jagung dan kelompok P2 diberi pakan mengandung 30\% KBK yang difermentasi dengan Bioplus dan 70\% jerami jagung. Semua sapi diberi pakan konsentrat komersial sebesar $1 \%$ dari bobot badan. Sapi dipotong pada akhir perlakuan pakan dan dianalisis kualitas karkas dan daging serta komponen non karkasnya. Rancangan penelitian yang digunakan adalah rancangan acak lengkap pola searah. Hasil penelitian menunjukkan bahwa persentase karkas, tebal lemak punggung, rib eye area dan indek perdagingan sapi Bali berturut-turut adalah sebagai berikut kelompok PO 53,33\%, 3,08 mm, 59,65 $\mathrm{cm}^{2}, 0,79 \%$; kelompok P1 52,64\%, 5,31 mm, 58,52 cm, 0,82\% dan kelompok P2 52,32\%, 5,7 mm, $57,75 \mathrm{~cm}, 0,79 \%$. Adapun marbling dan kadar kolesterol sapi Bali berturut-turut adalah sebagai berikut kelompok PO 2,65\% dan 71,25 mg/100g; kelompok P1 2,12\% dan 48,75 mg/100g dan kelompok P2 $2,63 \%$ dan $74,50 \mathrm{mg} / 100 \mathrm{~g}$. Kesimpulan yang dapat ditarik adalah bahwa kulit buah kakao yang difermentasi dapat diberikan pada sapi Bali tanpa mempengaruhi kualitas karkas, non karkas, dan marbling serta kandungan kolesterol daging sapi Bali Jantan, sedangkan kualitas karkas yang terbaik didapatkan pada sapi Bali yang diberi pakan kulit buah kakao yang difermentasi tanpa tambahan inokulum dari luar.
\end{abstract}

Kata kunci: kakao fermentasi, karkas, marbling, kolesterol, sapi Bali

\begin{abstract}
The experiment was conducted to evaluate the effect of fermented cacao shell on the carcass quality, percentage of non carcass components, marbling and cholesterol content of Bali cattle. Nine Bali cattle of 1.5-2 year old and $165-175 \mathrm{~kg}$ weight were grouped into three feeding trials. The first group P0 was fed ration containing 30\% cacao shell fermented with its own microorganism and $70 \%$ corn straw, the second group P1 was fed ration containing 30\% cacao shell fermented with ruminal fluid and $70 \%$ corn straw, and the third group P2 was fed ration containing 30\% cacao shell fermented with Bioplus and $70 \%$ corn straw. All cattle were also given commercial concentrate amounting to $1 \%$ of their bodyweight. The cattle were slaughtered at the end of feeding trial and their carcasses, meat and non carcass components were analysed. Experimental design used was completely randomized design. The results showed that carcass percentage, back fat thickness, rib eye area and meat index of Bali cattle
\end{abstract}


were as follows group PO 53.33\%, $3.08 \mathrm{~mm}, 59.65 \mathrm{~cm}^{2}, 0.79 \%$; group P1 52.64\%, $5.31 \mathrm{~mm}, 58.52 \mathrm{~cm}$, $0.82 \%$ and group P2 $5.32 \%, 5.7 \mathrm{~mm}, 57.75 \mathrm{~cm}, 0.79 \%$, respectively. The marbling and cholesterol content of Bali beef were group PO $2.65 \%$ and $71.25 \mathrm{mg} / 100 \mathrm{~g}$, group P1 $2.12 \%$ and $48.75 \mathrm{mg} / 100 \mathrm{~g}$, and P2 $2.63 \%$ and $74.50 \mathrm{mg} / 100 \mathrm{~g}$. It could be concluded that fermented cacao shell could be used as feed ingredient without any effect on the carcass and meat quality, marbling and cholesterol contents of male Bali beef.

Keywords: fermented cocoa shell, carcass, marbling, cholesterol and Bali cattle

\section{INTRODUCTION}

Bali cattle are Indonesian indigenous livestock that readily adapted to tropical environment, have high rate of reproduction and do not select to any kind of feed given (Bandini, 1999). The potency of cacao wastes in Indonesia is very high since the vast area of cacao plantation of 1,852,900 ha with cacao production amounting to 723,000 ton (BPS, 2013) may produce approximately 3.5 million ton cacao waste per year. But utilisation of cacao wastes is still very limited, data in the year 2003 showed that the amount of cacao wastes produced was 1.876 .600 ton per year and only 94,503 ton (5.04\%) was used for feed of livestock. Actually cacao shell contains relatively high nutrients such as $6-12 \%$ crude protein, $27-31 \%$ cellulose, $10-13 \%$ hemicelulosa and $12-19 \%$ lignin. The very low utilization of cacao shell may be due to the antinutritive found in it especially theobromine that toxic to the animal (Indraningsih et al., 2006) and may cause dermatitis.

Cacao shell has to be treated using various ways such as physical, chemical and biological treatments to overcome the disadvantages before being utilised for the livestock (Indraningsih and Sani, 2005). Biological treatment or fermentation of cacao shell have been carried out using commercial inoculums such as EM4, urea, biofit, using various yeast (Rhizopus stolonifer LAU 07) to increase the protein content to $16 \%$ (Lateef et al, 2008), using Aspergillus spp, that may decrease the fibers of cacao shell (the amount of crude fiber, NDF, ADF were 33.00, 55.79 and $44.29 \%$ respectively) (Alemawor et al., 2009), and using Aspergillus oryzae to increase the crude protein of cacao shell with $8.74 \%$ (Munier, 2009). Rumen of livestock contains microorganisms such as protozoa $(76,33$ per $\mu 1)$, bacteria $\left(2.3 \times 10^{8}\right.$ $\mathrm{cfu} / \mathrm{g})$ and fungi $\left(1.9 \times 10^{3} \mathrm{cfu} / \mathrm{g}\right)$ that can degrade any low quality fiber feedstuffs (Purbowati et al., 2014). According to Omed et al.(2000) stated that there were many bacteria in ruminal fluid from family of Bacteriodes, Fusobacterium,
Streptococcus, Eubacterium, Ruminococcus and Lactobacillus. Several studies on ruminal fluid revealed that the addition of ruminal fluid could improve fermentation process (Arora, 1992) and it could certainly be used as inoculum for fermentation process (Gamayanti et al., 2012; Purbowati et al., 2014).

Carcass quality was influenced by breed, feed and feed technology, and handling of the carcass itself. Assessment of carcass quality generally through carcass percentage, weight and length of carcass, fleshing index, area of rib area, back fat thickness, score of cattle fatness, score of fat calour, score of meat colour and meat $\mathrm{pH}$ (Soeparno, 1998). Standar Nasional Indonesia (SNI) assessed the physical quality of meat based on the meat colour, fat colour, marbling, texture, cholesterol content and microbial meat (BSN, 2015).

To improve carcass quality and marbling of Bali beef cattle in order to utilise the abundant cacao shell, the experiment was needed to carry out. Simple technology (fermentation using several inoculums) was applied on the cacao shell to overcome the antinutritive of cacao shell as well as to improve the quality of cacao plantation waste before being utilised for the Bali cattle.

\section{MATERIALS AND METHODS}

\section{Materials}

Materials used in the experiment consisted of 9 male Bali cattle (1.5-2.0 year old) with the initial weight of $165-175 \mathrm{~kg}$. Ration for Bali cattle contained the fermented cacao shell. The experiment was conducted at Teaching Farm, Faculty of Animal Husbandry, University of Mataram starting from August to October 2014.

\section{Methods}

Fermented cacao shell was prepared as followed: chopped cacao shell was mixed with rice bran $1.5 \%$, urea $0.5 \%$ of the cacao shell weight and finally added some water containing inoculums. Mixtures of the ration were then put in 
the plastic bag and tightened to make anaerobic condition so that the fermentation process could be achieved. There were 3 types of fermented cacao shell prepared, firstly cacao shell fermented without any additional inoculum, secondly cacao shell fermented with ruminal fluid and lastly cacao shell fermented with Bioplus. Fermentation was carried out for 9 days. Fermented cacao shell was then allowed openly before giving to the cattle. The design of experiment used was completely randomized design.

Nine Bali cattle were divided randomly into three groups of feeding treatments consisting of group PO received ration containing 30\% fermented cacao shell without any additional inoculum and $70 \%$ corn straw, group $\mathrm{P} 1$ received ration containing $30 \%$ fermented cacao shell with inoculum of ruminal fluid and $70 \%$ corn straw, and group P2 received ration containing 30\% fermented cacao shell with inoculum of Bioplus and $70 \%$ corn straw. Besides that, all cattle of the three groups were also fed commercial concentrate amounting to $1 \%$ of each body weight. All cattle were raised for 1.5 month and at the end of the feeding trial, they were slaughtered according to Islamic halal slaughter method at slaughterhouse (RPH) of Majeluk Mataram. The variables observed were slaughter weight, carcass weight, carcass percentage, back fat thickness (BFT), rib eye area (REA), fleshing index (FI), meat bone ratio (MBR), degree of marbling, and meat cholesterol.

\section{Data Analysis}

The data collected were analysed using analysis of variance of Program SAS. Any mean diferrences were analyzed using Duncan New
Multiple Range Test.

\section{RESULTS AND DISCUSSION}

\section{Carcass Quality of Male Bali Cattle}

The results of experiment were presented in Table 1. Statistical analysis showed that rations containing different type of fermented cacao shell did not influence the carcass quality and non carcass percentage of male Bali cattle except the liver percentage $(\mathrm{P}<0.05)$. Carcass percentage of male Bali cattle fed with fermented cacao shell was relatively high $52.76 \%$, it did not differ from previous studies reported by Wiyatna (2007) $54.0 \%$ and Pane (1990) 52-57.7\%. Male Bali cattle fed with fermented cacao shell without inoculum resulted in the highest carcass percentage $53.33 \%$. Results of the experiment was also in agreement with the study carried out by Hapid and Rugayah (2009) reported that Bali cattle with body weight of 200-220 kg resulted in carcass percentage of $53.73 \%$. This results also did not differ very much with carcass percentage of various subtropical cattle such as Angus, Belgian Blue, Hereford, Jersey, Limousin, South Devon and Wagyu that possessed carcass percentage approximately $58.13 \%$ in average (Afolayan et al., 2002).

Bali cattle fed with ration $\mathrm{P} 0$ tended to give better carcass quality with higher MBR 3.9:1, larger REA $59 \mathrm{~cm}^{2}$, and thinner BFT $3.08 \mathrm{~mm}$, whereas cattle group $\mathrm{P} 1$ and $\mathrm{P} 2$ resulted in lower MBR 3.1:1 and 2.9:1 respectively; narrower REA $58.52 \mathrm{~cm}^{2}$ and $51.75 \mathrm{~cm}^{2}$, respectively. Male Bali cattle of this experiment possessed high MBR. In fact it was comparable to subtropical cattle breed such as Angus, Hereford, Limousin with MBR of

Table 1. Carcass Quality of Male Bali Cattle Fed Ration Containing Different Fermented Cacao Shell

\begin{tabular}{|c|c|c|c|}
\hline \multirow[b]{2}{*}{ Parameter Observed } & \multicolumn{3}{|c|}{ Ration Containing Cacao Shell Fermented with } \\
\hline & $\begin{array}{c}\text { No Additional } \\
\text { Inoculum (Ration P0) }\end{array}$ & $\begin{array}{l}\text { Ruminal Fluid } \\
\text { (Ration P1) }\end{array}$ & $\begin{array}{l}\text { Bioplus } \\
\text { (Ration P2) }\end{array}$ \\
\hline Carcass weight $(\mathrm{kg})^{\mathrm{ns}}$ & $98.28 \pm 1.06$ & $100.00 \pm 4.24$ & $96.00 \pm 1.41$ \\
\hline Carcass percentage $(\%)^{\mathrm{ns}}$ & $53.33 \pm 0.47$ & $52.64 \pm 0.12$ & $52.32 \pm 0.57$ \\
\hline $\mathrm{MBR}^{\mathrm{ns}}$ & $3.9: 1$ & $3.1: 1$ & 2.9:1 \\
\hline $\operatorname{REA}\left(\mathrm{cm}^{2}\right)^{\mathrm{ns}}$ & $59.65 \pm 0.64$ & $58.52 \pm 3.42$ & $51.75 \pm 8.98$ \\
\hline $\mathrm{BFT}(\mathrm{mm})^{\mathrm{ns}}$ & $3.08 \pm 0.28$ & $5.31 \pm 1.40$ & $5.70 \pm 0.85$ \\
\hline Fleshing Index $(\%)^{\mathrm{ns}}$ & $0.79 \pm 0.01$ & $0.82 \pm 0.07$ & $0.79 \pm 0.01$ \\
\hline
\end{tabular}

ns is not significant, $\mathrm{MBR}=$ meat bone ratio, $\mathrm{REA}=$ rib eye area, $\mathrm{BFT}=$ back fat thickness 
3.7:1 (Afolayan et al., 2002) and Spanish breed with MBR of 4.1:1 (Oliver et al., 2010).

The result of statistical analysis showed that there was not any different on the back fat thickness of Bali cattle fed with ration containing different fermented cacao shell. But Bali cattle of group PO possessed the thinnest BFT $3.08 \mathrm{~mm}$ compered to group P1 and P2 with BFT of 5.1 $\mathrm{mm}$ and $5.7 \mathrm{~mm}$ respectively. Carcass with BFT between $5-7 \mathrm{~mm}$ considered as medium carcass grade.

Fleshing index presented in Table 1 showed that all Bali cattle had lower fleshing index 0.79$0.82 \%$ compared to the previous study carried out by Wiyatna (2007) that Bali cattle below 3 year old had fleshing index less than $1 \%$, whereas above 3 year old had fleshing index $1.23 \%$. He also reported that Madura, PO and Australian Commercial Cross cattle had the fleshing index of $0.95 \%, 1.21 \%$ and $1,42 \%$ respectively. There was not any significant effect of different inoculum on the fleshing index of Bali cattle.

\section{Percentage of Non Carcass of Male Bali Cattle}

The percentage of non carcass of male Bali cattle fed ration containing fermented cacao shell were presented in Table 2 . The average percentage of non carcass of male Bali cattle fed ration containing fermented cacao shell was $45.38 \%$ composed of hide $9.19 \%$, head $5.70 \%$, blood $3.08 \%$, feet $2.70 \%$, liver $2.19 \%$, limfe $0.28 \%$, digestive organs $20.25 \%$, reproductive organs $0.64 \%$, and lungs and heart $1.35 \%$. The percentage of non carcass components of Bali cattle $(45,37 \%)$ was lower than Java cattle $(48,98 \%)$ reported by Lestari et al. (2010) indicating that Bali cattle possed higher percentage of carcass.

\section{Marbling and Cholesterol Content of Bali Beef Cattle}

The results of experiment of marbling and cholesterol content of male Bali cattle fed ration containing fermented cacao shell was presented in Table 3. Analysis of variance showed that type of inoculum did not influence marbling and cholesterol content of male Bali beef. The average of marling of male Bali cattle fed ration containing fermented cacao shell was $2.47 \%$.

Swatland (1984) stated that beef cattle containing $2.5 \%$ marbling was categorised as small amount of marbling. The marbling percentages of Bali cattle fed ration containing fermented cacao shell were low since the cattle used in the experiment were still 1.5-2 year old. Fermentation of cacao shell without inoculum produced the higher marbling and lower cholesterol content of Bali beef indicating that

Table 2. Percentage of Non Carcass Male Bali Cattle Fed Ration Containing Fermented Cacao Shell (\%)

\begin{tabular}{lccc}
\hline \multirow{2}{*}{\multicolumn{1}{c}{ Parameter Observed }} & \multicolumn{2}{c}{ Ration Containing Cacao Shell Fermented with } \\
\cline { 2 - 4 } & $\begin{array}{c}\text { No Additional } \\
\text { Inoculum (Ration P0) }\end{array}$ & $\begin{array}{c}\text { Ruminal Fluid } \\
\text { (Ration P1) }\end{array}$ & $\begin{array}{c}\text { Bioplus } \\
\text { (Ration P2) }\end{array}$ \\
\hline Hide $^{\mathrm{ns}}$ & $9.10 \pm 0.56$ & $9.21 \pm 0.33$ & $9.27 \pm 0.35$ \\
Head $^{\mathrm{ns}}$ & $5.70 \pm 0.04$ & $5.54 \pm 0.25$ & $5.86 \pm 0.21$ \\
Blood $^{\mathrm{ns}}$ & $2.83 \pm 0.50$ & $3.10 \pm 0.08$ & $3.32 \pm 0.16$ \\
Feet $^{\mathrm{ns}}$ & $2.72 \pm 0.08$ & $2.64 \pm 0.27$ & $2.73 \pm 0.06$ \\
Liver $^{\text {Limph }}{ }^{\mathrm{ns}}$ & $2.25 \pm 0.07^{\mathrm{a}}$ & $2.45 \pm 0.18^{\mathrm{b}}$ & $1.86 \pm 0.16^{\mathrm{c}}$ \\
Digestive tract $^{\mathrm{ns}}$ & $0.27 \pm 0.04$ & $0.29 \pm 0.01$ & $0.27 \pm 0.06$ \\
Reproduction tract $^{\mathrm{ns}}$ & $20.52 \pm 0.12$ & $20.05 \pm 0.30$ & $20.17 \pm 1.24$ \\
Lungs and Heart $^{\mathrm{ns}}$ & $0.61 \pm 0.01$ & $0.66 \pm 0.06$ & $0.64 \pm 0.11$ \\
\multicolumn{1}{c}{ Total } & $1.34 \pm 0.08$ & $1.29 \pm 0.14$ & $1.43 \pm 0.14$ \\
\hline
\end{tabular}

$\mathrm{a}, \mathrm{b}, \mathrm{c}:$ different superscript at the same row indicates significant $(\mathrm{P}<0.05)$

ns : not signifcant 
Tabel 3. Marbling and Cholesterol Content of Male Bali Cattle Fed Ration Containing Fermented Cacao Shell

\begin{tabular}{|c|c|c|c|}
\hline \multirow[b]{2}{*}{ Parameter Observed } & \multicolumn{3}{|c|}{ Ration Containing Cacao Shell Fermented with } \\
\hline & $\begin{array}{c}\text { No Additional } \\
\text { Inoculum (Ration P0) }\end{array}$ & $\begin{array}{l}\text { Ruminal Fluid } \\
\text { (Ration P1) }\end{array}$ & $\begin{array}{l}\text { Bioplus } \\
\text { (Ration P2) }\end{array}$ \\
\hline Marbling $(\%)^{\mathrm{ns}}$ & $2.65 \pm 0.92$ & $2.12 \pm 0.57$ & $2.63 \pm 0.92$ \\
\hline Cholesterol (mg/100g) ${ }^{\mathrm{ns}}$ & $38.75 \pm 4.27$ & $38.75 \pm 2.63$ & $42.00 \pm 4.97$ \\
\hline
\end{tabular}

$\mathrm{ns}=$ not significant

Ration Containing Cacao Shell Fermented with

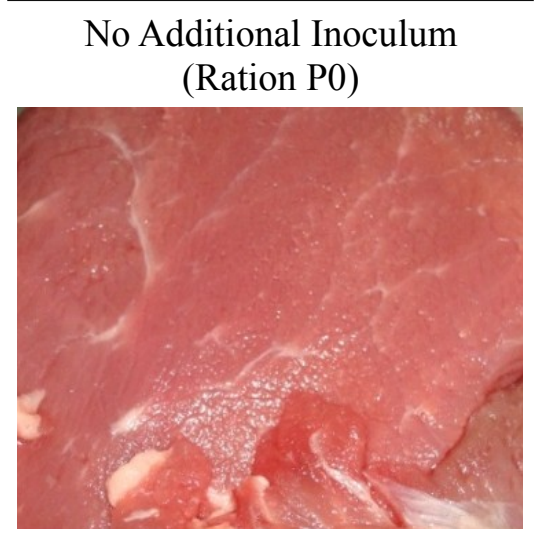

Small $(2.65 \%)$
Ruminal Fluid (Ration P1)

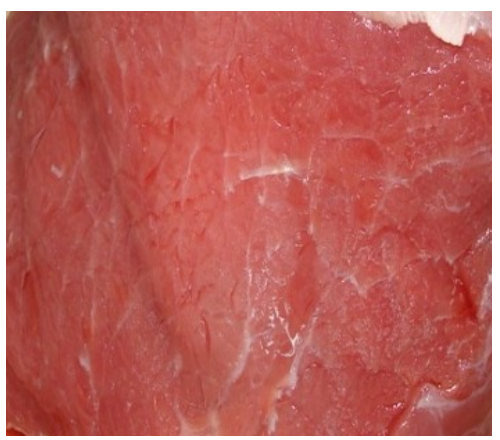

Small (2.12\%)
Bioplus (Ration P2)

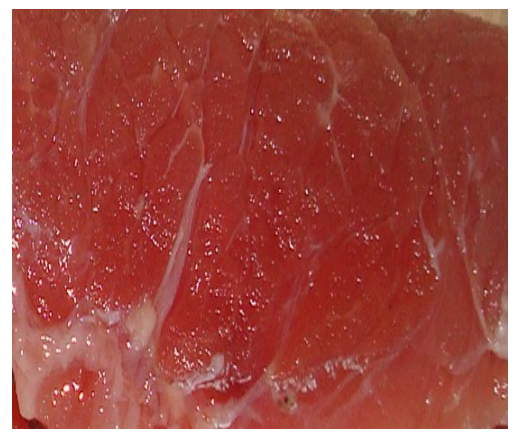

Small $(2.63 \%)$

Figure 1. Marbling Evaluated at Rib Eye Area of Male Bali Cattle Fed Ration Containing Fermented Cacao Shell

this simple fermentation might be good alternative to improve cacao shell quality (Figure 1). According to Soeparno (1998) the percentage of intramusculer fat (marbling) usually increased as the percentages of fat tissue and back fat thickness increased. Marbling content was influenced by the feed given to the animals since their life. The cattle that received feed containing cereal tend to result in more marbling and intermusculer fat compared to the animals that fed more grass or roughage.

The results of the experiment showed that the average cholesterol content of meat of male Bali cattle fed ration containing fermented cacao shell was $39.83 \mathrm{mg} / 100 \mathrm{~g}$. This was lower compared to the cholesterol content of beef reported by Saidin (2000) $65 \mathrm{mg} / 100 \mathrm{~g}$ and USDA Handbooks (1989) $73.1 \mathrm{mg} / 100 \mathrm{~g}$.

\section{CONCLUSION}

Ration containing fermented cacao shell could be given to Bali cattle and produced good carcass and high carcass percentage that comparable to the previous studies. Ration containing fermented cacao shell without additional inoculum resulted in the best carcass in term of the highest MBR and REA, the thinness BFT as well as the lowest non carcass percentage compared to other rations.

\section{REFERENCES}

Alemawor, F.,V.P. Dzogbefial, E.O.K. Oddoye and J.H. Oldham. 2009. Effect of pleurotus ostreatus fermentation on cocoa pod husk composition: Influence of fermentation 
period and $\mathrm{MN}^{2+}$ supplementation on the fermentation process. African J. Biotechnol. 8(9): 1950-1958

Afolayan.R.A, M.P.B. Deland, D.L. Rutley, C.D.K. Bottema, A.L. Ewers, R.W. Ponzoni and W.S. Pitchford. 2002. Prediction of carcass meat, fat and bone yield across diverse cattle genotypes using live-animal measurements. Anim. Prod. Aust. 2002. 24:13-16

Arora, S.P. 1992. Pencernaan Mikrobia pada Ruminansia. Gadjah Mada Univesity Press. Yogyakarta

Bandini, Y. 1999. Sapi Bali Cocok untuk Ternak Potong dan Kerja, Rajin Beranak dan Mudah Pemeliharaannya. Penebar Swadaya. Jakarta.

BPS. 2013. Produksi Kakao di Indonesia. Badan Pusat Statistik.

BSN (Badan Standarisasi Nasional). Standar Nasional Indonesia, Jakarta.

Gamayanti, K.N., A. Pertiwiningrum and L.M. Yusiati. 2012. Pengaruh penggunaan limbah cairan rumen dan lumpur gambut sebagai starter dalam proses fermentasi metanogenik. Buletin Peternakan.36(1):3239.

Hapid H. and Rugayah. 2009. Persentase Karkas Sapi Bali pada Berbagai Berat Badan dan Lama Pemuasaan Sebelum Pemotongan. Prosiding Seminar Nasional Teknologi Peternakan dan Veteriner. Bogor, 13-14 August, 2009. Pp. 77-85.

Indraningsih and Y. Sani. 2005. Kajian kontaminasi pestisida pada limbah padi sebagai pakan ternak dan alternatif penanggulangannya. Pros. Seminar Nasional Pengembangan Usaha Peternakan Berdaya Saing di Lahan Kering. Puslitbang Peternakan-Universitas Gadjah Mada. Pp. 108-119.

Indraningsih, R. Widiastuti and Y. Sani. 2006. Upaya Pengembangan Peternakan Kerbau dalam Menunjang Kecukupan Daging Prosiding Lokakarya Nasional Usaha Ternak Kerbau Mendukung Program Kecukupan Daging Sapi 2006 Puslitbang Peternakan. Sumbawa, Nusa Tenggara Barat, 4 August 2006. Pp 124-140.

Lestari, C.M.S., Y. Hudoyo and S. Dartosukarno. 2010. Proporsi karkas dan komponenkomponen nonkarkas sapi Jawa di rumah potong hewan swasta kecamatan Ketanggungan kabupaten Brebes. Prosiding
Seminar Nasional Teknologi Peternakan dan Veteriner 2010. Bogor 3-4 Agugust 2010. Pp 296-300.

Lateef, A., J.K. Oloke., E.B. Gueguim Kana, S.O. Oyeniyi, O.R. Onifade, A.O. Oyeleye, O.C. Oladusu and A.O. Oyelami. 2008. Improving the quality of agro-wastes by solid-state fermentation: Enhanced antioxidant activities and nutritional qualities. World J.Microbiol. Biotechnol. 24: 2369-2374.

Munier, F.F. 2009. Komposisi Kimia pada Kulit Buah Kakao (Theobroma cacao L.) yang Difermentasi dengan Aspirgillus oryzae. Balai Pengkajian Teknologi Pertanian Sulawesi Tengah.

Oliver, A., J.A. Mendizabal, G. Ripoll, P. Alberti, and A. Purroy. 2010. Predicting meat yields and commercial meat cuts from carcass of young bulls of Sapnish breeds by the SEUROP method and an image analysis system. Meat Sci. 84: 628-633.

Omed, H.M., D.K. Lovetland, and R.F.E. Axford, 2000. Faeces as a source of microbial enzymes for estimating digestibility. In: Forage evaluation in ruminant nutrition. D.I. Givens, E.Owen, F.R.E. Axford and H.M. Omed (eds), CABI Publishing, New York Pp. 135-150.

Pane, I. 1990. Pelaksanaan Perbaikan Mutu Genetik Sapi Bali. Prosiding Seminar Nasional Upaya Peningkatan Mutu Genetik Sapi Bali. Bali, 20-22 September 1990, Pp. A42 - A46.

Purbowati, E., E. Rianto, W.S. Dilaga, C.M.S. Lestari and R. Adiwinarti. 2014. Karakteristik cairan rumen, jenis dan jumlah mikrobia dalam rumen sapi Jawa dan Peranakan Ongole. Buletin Peternakan. 38(1):21-26

Saidin, M. 2000. Kandungan Kolesterol Dalam Berbagai Bahan Makanan Hewani. Buletin. Pusat Penelitian dan Pengembangan Gizi, Badan Litbangkes, Depkes RI.

Soeparno. 1998. Ilmu dan Teknologi Daging. $3^{\text {rd }}$ ed, Gadjah Mada University Press, Yogyakarta. Pp 62-69, 131-134.

Swatland, H. J. 1984. Structure and Development of Meat Animals. Prentice Hall, Inc., Englewood Cliffs, New Jersey.

USDA Handbooks. 1989. Nutritive Value of Foods. Home and Garden Bulletin. Washington DC. Government Printing Office. 
Wiyatna, M.F. 2007. Perbandingan indek perdagingan sapi-sapi Indonesia (Sapi Bali, Madura, PO) dengan sapi Australian
Commercial Cross (ACC). Jurnal Ilmu Ternak. 7(1): 22-25 